\title{
UPAYA DETEKSI DAN PENCEGAHAN PERUNDUNGAN (BULLYING) DI SMPN SATU ATAP DESA SUKA MAJU KEC. MESTONG KAB. MUARO JAMBI
}

\author{
Mila Triana Sari ${ }^{1}$, Daryanto ${ }^{2}$ \\ 1,2 Program Studi Profesi Ners STIKes Baiturrahim Jambi \\ Email:milatrianasari273@yahoo.com
}

\begin{abstract}
Cases of bullying or violence against children in Indonesian schools currently rank second largest after Japan. While the United States itself is under Indonesia. (Indra, 2016). As many as 84 percent of children aged 12 years to 17 years have been victims of bullying (Viva, 2017). The impact on children who experience Bully will cause adverse effects such as reluctance to go to school, decreased learning achievement, tension, bruises or injuries on the body and ask to change schools and so on. One of the efforts that nurses can do is provide health education to students and teachers. One Roof Junior Secondary School is a partner school, which cares about bullying, but has never carried out health education activities on prevention of Bullying. The target and outcome of this activity to community service is to provide an understanding of the concept of bullying so that it can detect and make prevention efforts both as perpetrators and victims. The implementation method used is survey, observation, interview, discussion, question and answer through giving information about Bullying detection and prevention at the One Roof Junior High School of Suka Maju Village. The target of the Activity is all students and Teachers of One Roof Junior High School in Suka Maju Village, Kec. Mestong Kab. Muaro Jambi. The service activities are carried out starting from preparation, implementation and evaluation within April 24 to May 12, 2018. Before and after health education students are given questions about Bullying, detection and prevention. Students' knowledge about detection and prevention of bullying was measured before and 1 week after counseling. Results of the activity A total of 45 students and 4 teachers participated in the implementation. Most participants considered that health education activities were beneficial for them in early detection and actively made efforts to prevent bullying both as victims and perpetrators among students and teachers.
\end{abstract}

Keywords: Detection, Bullying Prevention, Teenager

\begin{abstract}
ABSTRAK
Kasus bullying atau kekerasan terhadap anak di sekolah Indonesia saat ini mendapatkan peringkat kedua terbesar setelah Jepang. Sementara Amerika Serikat sendiri berada di bawah Indonesia. (Indra, 2016). Sebanyak 84 persen anak usia 12 tahun hingga 17 tahun pernah menjadi korban bullying (Viva, 2017). Dampak bagi anak yang mengalami Buli akan menimbulkan efek kurang baik seperti enggan ke sekolah, prestasi belajar menurun, tegang, memar atau luka di tubuh dan minta pindah sekolah dan sebagainya.Salah satu upaya yang dapat dilakukan perawat adalah memberikan pendidikan kesehatan pada siswa dan guru.SMP Satu Atap adalah salah satu sekolah mitra, yang belum pernah melakukan kegiatan pendidikan kesehatan pencegahan Bulllying. Target dan luaran kegiatan kepada pengabdian masyarakat ini adalah memberikan pemahaman konsep bullying sehingga dapat mendeteksi sekaligus melakukan upaya pencegahan baik sebagai pelaku maupun korban. Metode pelaksanaan yang digunakan adalah survey,observasi, wawancara,diskusi,tanya jawab melalui pemberian penyuluhan tentang deteksi dan pencegahan Bullying di sekolah SMPN Satu Atap Desa Suka Maju. Sasaran Kegiatan adalah seluruh siswa dan Guru SMPN Satu Atap desa Suka Maju Kec. Mestong Kab. Muaro Jambi. Kegiatan pengabdian dilaksanakan mulai persiapan, pelaksanaan dan evaluasi dalam kurun waktu 24 April sd 12 Mei 2018. Sebelum dan sesudah pendidikan kesehatan siswa diberikan pertanyaan
\end{abstract}


seputar Bullying, deteksi dan pencegahanya. Pengetahuan siswa tentang deteksi dan pencegahan Bullying diukur sebelum dan 1 minggu setelah penyuluhan. Hasil kegiatan Sebanyak 45 Siswa dan 4 orang guru telah berpartisipasi dalam pelaksanaan. Sebagian besar peserta menilai bahwa kegiatan pendidikan kesehatan bermanfaat bagi mereka dalam deteksi dini dan aktif melakukan upaya pencegahan Bullying baik sebagai korban maupun pelaku di kalangan siswa serta guru.

Kata kunci: Upaya Deteksi, Pencegahan Bullying, Remaja

\section{PENDAHULUAN}

Kekerasan merupakan suatu hal yang paling banyak ditakuti oleh manusia. Baik kekerasan langsung maupun tidak langsung, baik kekerasan verbal maupun non verbal. Bentuk kekerasan yang paling sering terjadi di sekolah adalah bullying. Menurut penelitian yang dilakukan untuk pemerintah pada 2009, hampir separuh anak-anak di Inggris (46 persen) berkata mereka pernah di-bully. Bullying tidak memilih umur atau jenis kelamin korban. Biasanya yang menjadi korban pada umumnya adalah anak yang lemah, pemalu, pendiam, dan special (cacat, tertutup, pandai, cantik, atau punya ciri tubuh tertentu), yang dapat menjadi bahan ejekan.

Kasus bullying atau kekerasan terhadap anak di sekolah Indonesia saat ini mendapatkan peringkat kedua terbesar setelah Jepang. Sementara negara Amerika Serikat sendiri berada di bawah Indonesia. (Indra, 2016). Kementerian Sosial. Dari data survei, sebanyak 84 persen anak usia 12 tahun hingga 17 tahun pernah menjadi korban bullying (Viva, 2017).

Kasus bullying atau perundungan pada anak-anak meningkat dan tidak bisa dibiarkan, karena akan menimbulkan masalah serta meresahkan masyarakat. Bullying menjadi perhatian. Di Indonesia sendiri, kasus bullying di sekolah sudah merajalela. Baik di tingkat sekolah dasar, menengah, sampai perguruan tinggi. Dari 2011 hingga Agustus 2014, KPAI mencatat 369 pengaduan terkait masalah tersebut. Jumlah itu sekitar $25 \%$ dari total pengaduan di bidang pendidikan sebanyak 1.480 kasus. Bullying yang disebut KPAI sebagai bentuk kekerasan di sekolah, mengalahkan tawuran pelajar, diskriminasi pendidikan, ataupun aduan pungutan liar. Komisi Perlindungan Anak Indonesia (KPAI) menerima 26 ribu kasus anak dalam kurun 2011 hingga September 2017. Laporan tertinggi yang diterima KPAI adalah anak yang berhadapan dengan hukum (Indrawan, 2017). Women (ICRW) pada 2015, sekitar 84\% anak muda di Indonesia mengalami kekerasan di sekolah. Angka tersebut jauh di atas angka rata-rata di Asia yang ada di kisaran $70 \%$.

Bullying antar siswa yang semakin marak terjadi di sekolah telah menunjukkan tingkat yang memprihatinkan. Tingkat emosional siswa yang masih labil, memungkinkan perilaku bullying ini sering terjadi di kalangan para siswa. Salah satu bentuk emosi yang diidentifikasikan oleh Daniel Goleman (1995) adalah amarah. Amarah di dalamnya meliputi brutal, mengamuk, benci, marah besar, jengkel, kesal hati, terganggu, rasa pahit, berang, tersinggung, bermusuhan, tindak kekerasan, dan kebencian patologis. Bullying juga terjadi karena adanya kesenjangan kelas yang sangat kentara. Menurut Bourdieu, bahwa selera gaya hidup serta konsepsi yang dimiliki setiap kelas mengenai dirinya, terutama dalam masalah peran sosial yang dimainkannya. Perbedaan kelas ini yang bisa memicu terjadinya bullying antar siswa, karena adanya perbedaan kepentingan serta gaya hidup yang berbeda pula.

Efek dari Buli ini terhadap anak beragam. Seperti enggan ke sekolah, mengalami 
penurunan nilai. Bertingkah tegang pada saat anak lain mendekat. Adanya tandatanda fisik seperti memar atau luka di tubuh. Prestasi belajar menurun. Minta pindah sekolah dan banyak lagi efek lainnya,"(Indra, 2015)

Mempertimbangkan beratnya dampak yang ditimbulkan, maka tindakan Bullyng perlu dilakukan upaya deteksi dan pencegahan orang tua di lingkungan keluarga, pemuka masyarakat yang ada di lingkungan tempat tinggal, serta kepala sekolah dan segenap guru di lingkungan sekolah.

Masalah bullying saat ini sedang marak terjadi di lingkungan sekolah di Negara lain termasuk kasus yang terjadi di Sekolahsekolah yang ada di beberapa kota besar di Indonesia dalam beberapa tahun terakhir ini. Untuk itu upaya deteksi dan pencegahan bullying di lingkungan sekolah perlu dilakukan. SMP Satu Atap merupakan salah satu SMP di Mestong yang peduli terhadap upaya deteksi dan pencegahan masalah Bullying, meskipun hingga saat ini belum pernah ada laporan atau pengaduan terkait masalah bullyng di SMP satu Atap. Disamping itu, berdasarkan informasi dari kepala Sekolah, bahwa kegiatan pendidikan kesehatan tentang pencegahan bullying di sekolah belum pernah di lakukan. Oleh karena itu, tim pengabdian masyarakat bermaksud melaksanakan kegiatan pengabdian masyarakat yang berjudul "Upaya Deteksi dan Pencegahan Perundungan (Bullying) di SMPN Satu Atap Desa Suka Maju Kec. Mestong Muaro Jambi"

\section{TARGET DAN LUARAN}

Target dari kegiatan pengabdian ini ada seluruh siswa dan guru pada SMP Nę

Satu Atap. Luarannya adalah meningkatkan pengetahuan siswa dan guru tentang deteksi tanda dan gejala, melakukan pencegahan dan mengatasi dampak Bullying di lingkungan sekolah.

\section{METODE PELAKSANAAN}

Kegiatan pengabdian kepada masyarakat ini dilakukan di SMP Negeri Satu Atap kec. Mestong Kab. Muaro Jambi, selama 2 bulan yaitu 24 April - 12 Mei 2018. Metode pelaksanaan yang digunakan adalah survey, observasi, wawancara, ceramah, tanya jawab dan dalam bentuk pemberian pendidikan kesehatan. Sebelum dan sesudah pendidikan kesehatan siswa diberikan pertanyaan seputar Bullying, deteksi dan pencegahannya. Kegiatan ini dilakukan di Ruang Laboratorium SMP Negeri Satu Atap, diikuti oleh 49 orang siswa dan 4 orang guru. Materi yang diberikan tentang konsep bullying, deteksi dan pencegahan bullying. Selain mitra dan pelaksana, kegiatan ini dibantu oleh 2 orang mahasiswa Program Studi Ilmu keperawatan STIKes Baiturrahim Jambi.

\section{HASIL DAN PEMBAHASAN}

Hasil kegiatan pengabdian kepada masyarakat yang telah dilaksanakan dengan mitra SMP Negeri Satu Atap adalah sebagai berikut:

I. Hasil pengisian kuesioner factor deteksi dan pencegahan Bullying dapat dilihat pada tabel 1. disamping ini :

Tabel 1. Hasil Skrining Deteksi dan Pencegahan Bullying pada siswa SMPN Satu Atap Suka Maju Kec. Mestong Muaro Jambi Tahun 2018

\begin{tabular}{clcc} 
No & Aspek & Jumlah & Persen \\
\hline 1 & Korban & 10 & 22,3 \\
2 & Pelaku & 3 & 6,7 \\
3 & Netral & 27 & 60 \\
& Jumlah & 45 & $100 \%$ \\
\hline
\end{tabular}

Berdasarkan data tabel 1. skrining Bullying diperoleh gambaran bahwa sekitar $60 \%$ 
Siswa termasuk memiliki factor risiko namum belum sebagai korban atau pelaku. $22,3 \%$ pernah mengalami bullying secara verbal dan tidak pernah secara fisik. Sekitar $6,7 \%$ pernah melakukan Bullying secara verbal kepada temannya baik secara sengaja maupun tidak sengaja.

Temuan ini masih dibilang dalam batas wajar dan bahkan angkanya cukup rendah bila dibandingkan dengan angka nasional 84 \% (ICRW,2015). Definisi bullying sendiri, menurut Komisi Nasional Perlindungan Anak adalah kekerasan fisik dan psikologis berjangka panjang yang dilakukan seseorang atau kelompok terhadap seseorang yang tidak mampu mempertahankan diri. Dapat dikatakan pula bullying adalah tindakan yang dilakukan seseorang secara sengaja membuat orang lain takut atau terancam sehingga menyebabkan korban merasa takut, terancam, atau setidak-tidaknya tidak bahagia.

Menurut Riauskina dkk dalam Hengki (2014), penyebab terjadinya Bullying di sekolah diantaranya: Bullying merupakan tradisi turun menurun dari senior, balas dendam karena pernah mendapat perlakuan yang sama (menurut korban laki-laki), ingin menunjukkan kekuasaan, marah karena korban tidak berperilaku sesuai yang diharapkan, mendapatkan kepuasan (menurut korban perempuan), Perilaku dianggap tidak sopan menurut ukuran kelompok tertentu.

Menurut Setiawati (seperti dikutip dari Usman), kecenderungan pihak sekolah yang sering mengabaikan keberadaan bullying menjadikan siswa yang menjadi pelaku bullying semakin mendapatkan penguatan terhadap perilaku tersebut. Selain itu, bullying dapat terjadi di sekolah jika pengawasan dan bimbingan etika dari para guru rendah, sekolah dengan kedisiplinan yang sangat kaku, bimbingan yang tidak layak dan peraturan yang tidak konsisten. Dalam penelitian oleh Adair, 79\% kasus bullying di sekolah tidak dilaporkan ke guru atau orang tua. Siswa cenderung untuk menutup-nutupi hal ini dan menyelesaikannya mencerminkan kemandirian. dengan teman sepermainannya di sekolah.

Meskipun angka kejadian bullying cukup rendah, kewaspadaan siswa dan guru terhadap factor risiko Bullying masih perlu ditingkatkan sebagai antisipasi jangan sampai kasus bullying tidak terjadi. Pencegahan yang diperlukan adalah menerapkan pola perilaku hidup sehat jiwa bagi setiap individu baik guru dan siswa, keluarga dan masyarakat misalnya menerapkan komunikasi, sikap dan berperilaku yang baik. Upaya pencegahan tersebut dimulai bagi diri sendiri di lingkungan sekolah, keluarga dan lingkungan social.

Hasil pengisian kuesioner pengetahuan deteksi dan pencegahan Bullying dapat dilihat pada tabel 2. berikut ini :

Tabel 2. Hasil Pengetahuan Deteksi dan Pencegahan Bullying siswa SMPN satu Atap Desa Suka Maju Kec. Mestong Muaro Jambi Tahun 2018

\begin{tabular}{llcc}
\hline NO & $\begin{array}{l}\text { Rentang } \\
\text { Pengetahuan }\end{array}$ & $\begin{array}{c}\text { Jumlah } \\
\text { Pretest }\end{array}$ & $\begin{array}{c}\text { Jumlah } \\
\text { Post } \\
\text { Test }\end{array}$ \\
\hline 1. & Baik & 5 & 23 \\
2. & Cukup & 8 & 18 \\
3. & Kurang & 32 & 4 \\
& Jumlah & 45 & 45 \\
\hline
\end{tabular}

Berdasarkan data tabel 2. skrining Bullying sebelum pemberian materi deteksi dan pencegahan Bullying pada siswa diperoleh gambaran bahwa 5 orang mendapat nilai baik, 8 orang mendapat nilai cukup dan 32 orang mendapat nilai kurang. Setelah pemberian materi deteksi dan pencegahan Bullying, terjadi peningkatan pengetahuan yaitu 23 orang 
mendapat nilai baik $(51,1 \%), 18$ orang (40\%) mendapat nilai cukup dan 4 orang $(8,9 \%)$ mendapat nilai kurang.

Hal ini menggambarkan bahwa adanya peningkatan pengetahuan siswa setelah diberikan pendidikan kesehatan tentang deteksi dan pencegahan bullying. Pengetahuan tentang deteksi dan pencegahan bullying diharapkan dapat menumbuhkan kewaspadaan siswa dan guru tentang pentingnya pengenalan factor-faktor risiko dan tanda-tanda dini perilaku bullying sehingga dapat dilakukan upaya pencegahan sedini mungkin. Menurut Hidayati (2012) upaya pencegahan melalui sekolah dapat dilakukan dengan merancang dan membuat desain program pencegahan yang berisikan pesan kepada murid bahwa perilaku bully tidak diterima di sekolah dan membuat kebijakan "anti bullying", membangun komunikasi efektif antara guru dan murid, diskusi dan ceramah mengenai perilaku bully di sekolah, menciptakan suasana lingkungan sekolah yang aman, nyaman dan kondusif, menyediakan bantuan kepada murid yang menjadi korban bully, melakukan pertemuan berkala dengan orangtua atau komite sekolah.

\section{KESIMPULAN DAN SARAN}

\section{Kesimpulan}

1. Secara umum tingkat partisipasi sekolah baik siswa dan guru dalam deteksi dan pencegahan Bullying dalam pelaksanaan kegiatan pengabdian kepada masyarakat adalah sangat tinggi, dimana kegiatan telah dihadiri seluruh peserta (100 \%). Sekitar 22,3\% dari peserta pernah mengalami korban bullying, 6,7\% pernah sebagai pelaku dan sisanya $60 \%$ tidak pernah mengalami baik sebagai pelaku dan korban.

Pengenalan factor -faktor risiko dan deteksi tanda-tanda Bullying sangat diperlukan agar kasus Bullying tidak terjadi.

Kegiatan pengabmas dapat meningkatkan pengetahuan siswa tentang deteksi dan pencegahan Bullying dengan nilai Baik dari 5 orang menjadi 23 orang setelah kegiatan.

\section{Saran}

Disarankan kepada sekolah untuk dapat meningkatkan dan mempertahankan peran serta sekolah baik guru dan siswa SMPN Satu Atap dalam deteksi dan pencegahan Bullying di lingkungan sekolah, serta kepada petugas kesehatan PKM Pondok Meja khususnya bagian UKS untuk dapat memantau dan mensosialisasi tentang bullying di lingkungan sekolah.

\section{UCAPAN TERIMA KASIH}

Semua tim dan mitra pada kegiatan pengabdian ini mengucapkan terima kasih kepada:

1. Kepala Dinas Kesehatan Kab Muaro Jambi beserta jajarannya.

2. Kepala UPTD Puskesmas Pondok Meja beserta jajarannya.

3. Mitra dari Puskesmas Pondok Meja terutama penanggung jawab dan pelaksana kegiatan konseling dan Unit UKS.

4. Ketua STIKes Baiturrahim Jambi beserta jajarannya.

5. Mahasiswa Program Studi SI Keperawatan STIKes Baiturrahim Jambi.

6. Semua pihak yang membantu terlaksananya kegiatan ini.

\section{DAFTAR PUSTAKA}

Dinas Kesehatan Provinsi Jambi., 2017. Profil kesehatan provinsi jambi. Jambi: Dinkes Provinsi Jambi.

Glanz, K., Rimer, B.K., \& Viswanath, K., 2008. Health behavior and health education: Theory, research, and 
practice (4th ed.). San Francisco: Jossey Bass.

Hidayati, N. 2012. Bullying pada Anak: Analisis

dan Alternatif Solusi. Fakultas Psikologi

Universitas Muhammadiyah Gresik. INSANVol. 14 No. 01, April 2012

Indrawan A.F. 2017. KPAI Terima Aduan 26 Ribu Kasus Bully Selama 2011-2017. detikNews. Rabu 04 Oktober 2017, 14:15 WIB

Indra, Z. 2015. Indonesia Ranking Kedua BullyingSedunia. http://pekanbaru. tribunnews. com /2015/04/28/ indonesia-ranking-kedua-bullyingsedunia. Diakses tanggal 15 Februari 2018.

Lestari W.S.(2016). Analisis Faktor-faktor penyebab Bullying di kalangan peserta didik. SOSIO DIDAKTIKA: Social Science Education Journal, Vol. 3 No. 2 Tahun 2016.

O'Connell J. 2003. Bullying at School. the Counseling and Student Support Office, California Department of Education. ISBN 0-8011-1584-1

Pepler D and Craig W. 2014. Bullying Prevention and Intervention in the School Environment: Factsheets and Tools.

Putra YM. 2016. Dampak negative perundungan Siber. Republika. Senin 22 August 2016 20:47 WIB.

Rastati R.2016. Bentuk perundungan di Siber Media Sosial dan pencegahanya bagi korban dan pelaku. Vol 15, No 2 .

Surilena. 2016. Perilaku Bullying (Perundungan) pada Anak dan Remaja. Departemen Psikiatri, Fakultas Kedokteran Universitas Katolik Atma Jaya, Jakarta, Indonesia.

Sobatask. 2018. 4 Fakta Bullying di Indonesia. https://www.sobatask. net/2017/ indonesia/.

Sobatask. 2018. Enam langkah kalau kamu jadi korban bullying. https://www.sobatask. net/2017/09/6langkah-kalau-kamu-jadi-korbanbullying/

Unicef.org/indonesia/id/Laporan_Tahunan_ UNICEF_Indonesia_2015.pdf

Viva. 2017. Kasus Bullying Anak Meningkat pada 2017. https://www.viva.co.id/berita/ nasional/938446-kasus-bullying-anakmeningkat-pada-2017. diakses tanggal 15 Februari 2018.

Kementerian Kesehatan Republik Indonesia., 2014. Permenkes RI nomor 75 tahun 2014 tentang puskesmas. Jakarta: Kemenkes, R.I.

Notoatmodjo, S., 2012. Ilmu perilaku kesehatan kesehatan. Jakarta: Rineka Cipta. Puskesmas Pondok Meja., 2018. Profil Puskesmas Pondok Meja Tahun 2017. Jambi: Puskesmas Pondok meja. 